\title{
PENCARIAN RUTE TERDEKAT PELAKU USAHA MIKRO, KECIL DAN MENENGAH DI KABUPATEN MALANG PADA ANDROID DENGAN MENGGUNAKAN METODE FLOYD WARSHALL (STUDI KASUS DI DISKOMINFO KABUPATEN MALANG)
}

\author{
Mungki Astiningrum ${ }^{1}$, Dika Rizky Yunianto ${ }^{2}$, Diva Adittiyaputra ${ }^{3}$ \\ 1,2,3 Teknologi Informasi, Teknik Informatika, Politeknik Negeri Malang \\ ${ }^{1}$ mungki.astingrum@polinema.ac.id, ${ }^{2}$ dikarizkyyunianto@polinema.ac.id, ${ }^{3}$ divaaditt@gmail.com
}

\begin{abstract}
Abstrak
DISKOMINFO Kabupaten Malang menjelaskan, salah satu masalah yang sering kali di alami oleh masyarakat di Kabupaten Malang adalah banyaknya pelaku usaha yang tidak terdaftar dalam aplikasi Google Maps yang menjadikan pencarian lokasi pelaku usaha masih tergolong kurang efisien. Selain itu, tidak adanya sistem menyulitkan DISKOMINFO dalam mengelola data UMKM dan lokasi dari pelaku usaha. Berdasarkan permasalah tersebut, dibutuhkan sebuah sistem yang dapat membantu masyarakat yang berada di Kabupaten Malang dalam mengetahui informasi UMKM dan melakukan pencarian rute terdekat menuju pelaku usaha. Dibutuhkan juga halaman admin yang dapat memudahkan DISKOMINFO dalam mengelola data informasi UMKM. Untuk melakukan pencarian rute terdekat, akan digunakan metode Floyd Warshall, yang diterapkan dalam perhitungan untuk mencari rute dengan bobot terkecil sehingga didapatkan rute yang akan dipilih untuk menuju pelaku usaha. Peta yang akan digunakan adalah peta yang berasal dari Google dan aplikasi yang dibangun berbasis android. Dari pengujian yang telah dilakukan dalam penelitian ini, didapat bahwa aplikasi yang telah dibuat mampu memberikan hasil yang efisien dalam menentukan rute terdekat menuju pelaku usaha.
\end{abstract}

Kata kunci : Pencarian Rute Terdekat, UMKM, Android, Floyd Warshall

\section{Pendahuluan}

Usaha mikro, kecil, dan menengah (UMKM) memegang peranan yang sangat penting dalam memajukan perekonomian Indonesia. Eksistensi UMKM tidak dapat diragukan lagi karena terbukti mampu bertahan dan menjadi roda penggerak ekonomi, terutama pasca krisis ekonomi (Pangestuti, Endriana dkk., 2018). Ketika krisis menerpa pada periode 1997-1998, hanya UMKM yang mampu tetap berdiri kokoh. Data Badan Pusat Statistik memperlihatkan, pasca krisis ekonomi pada tahun 1997-1998 jumlah UMKM tidak berkurang dan justru meningkat terus, bahkan mampu menyerap tenaga kerja sampai tahun 2012 (Putra, 2016). Saat ini UMKM dijadikan pilar ekonomi kerakyatan. Sebagai pilar ekonomi kerakyatan UMKM dapat dirasakan pengaruhnya pada kota kecil maupun besar. Banyak pedagang dan pengusaha kecil yang aktif mengambil bagian dalam kehidupan ekonomi. Banyak penjual makanan, warung makan, restoran, penjualan jasa, pedagang, dan masih banyak lagi yang ikut menumbuhkan perokonomian negara (Jubille Enterprise, 2016). Walaupun UMKM sangat berperan dalam mengurangi tingkat pengagguran yang ada di Indonesia, akan tetapi masih ada beberapa pelaku usaha khususnya di Kabupaten Malang yang belum memaksimalkan penggunaan teknologi untuk mengembangkan usahanya. Hal tersebut mengakibatkan kurangnya pemasaran, jaringan pasar yang sempit, informasi tentang barang apa yang di produksi dan lokasi dari pelaku usaha tersebut. Penerapan teknologi dapat dilakukan baik untuk melakukan promosi dan penyampaian informasi pelaku usaha maupun informasi rute dari berbagai UMKM yang ada.

DISKOMINFO Kabupaten Malang menjelaskan, salah satu masalah yang sering kali di alami oleh masyarakat di Kabupaten Malang adalah banyaknya pelaku usaha yang tidak terdaftar dalam aplikasi Google Maps yang menjadikan pencarian rute menuju pelaku usaha masih tergolong kurang efisien. Sebagai contoh, terdapat dua pelaku usaha yang memproduksi barang yang sama dan salah satu dari pelaku usaha tersebut tidak terdaftar dalam aplikasi Google Maps akan tetapi, dari jarak sesungguhnya salah satu pelaku usaha tersebut memiliki jarak yang lebih dekat dari pengguna. Dari permasalahan tersebut maka dimanfaatkan teknologi informasi yang nantinya dapat digunakan sebagai media dalam mempromosikan sebuah UMKM dan mempermudah masyarakat dalam mencari rute terdekat menuju pelaku usaha yang tertuang dalam bentuk Sistem Informasi Geografis (SIG) berbasis android. SIG sendiri merupakan sebuah komputer yang berbasis sistem informasi digunakan untuk memberikan informasi bentuk digital dan analisis terhadap permukaan geografi bumi (Awangga, 2019). 
Dalam pemanfaatanya, digunakan data longitude dan latitude untuk penandaan setiap lokasi pelaku usaha. Data tersebut juga nantinya akan digunakan dalam perhitungan algoritma untuk mencari rute terdekat. Pada pencarian rute terdekat, terdapat beberapa algoritma yang dapat digunakan untuk mencari rute terdekat yang salah satunya adalah algoritma Floyd Warshall. Algoritma ini menghitung bobot terkecil dari semua jalur yang menghubungkan sebuah pasangan titik dan melakukannya sekaligus untuk semua pasangan titik demi titik hingga mencapai titik tujuan dengan jumlah bobot yang paling minimum (Widya \& Andrasto, 2016).

Oleh sebab itu, pada penilitian ini diusulkan sebuah sistem yang memanfaatkan SIG ini, diharapkan dapat membantu masyarakat Kabupaten Malang dalam mencari informasi dan rute terdekat menuju pelaku usaha yang ingin dicari dengan menggunakan smartphone. Selain bagi masyarakat diharapkan juga sistem ini dapat membantu DISKOMINFO Kabupaten Malang dalam mengatur dan mengelola data UMKM.

\section{Tinjauan Pustaka}

\subsection{Pencarian Rute Terdekat}

Masalah dalam pencarian rute terpendek berkaitan dengan penentuan busur-busur yang saling terhubung dalam sebuah jaringan yang secara bersama-sama membuat jarak terdekat diantara sumber dan tujuan. Jarak terpendek merupakan bagian dari teori graf. Jika diberikan sebuah graf berbobot, masalah jarak terpendek adalah bagaimana mencari sebuah jalur pada graf yang meminimalkan jumlah bobot sisi pembentuk jalur tersebut. Graf sendiri merupakan himpunan tidak kosong antara pasangan simpul- simpul dan sisi-sisi yang menghubungkan sepasang simpul. Himpunan simpul tidak boleh kosong, sedangkan himpunan sisi boleh kosong (Kusmira \& Taufiqurrochman, 2017).

Pada aplikasi ini pencarian rute terdekat digunakan untuk mencari jalur terdekat menuju lokasi pelaku usaha. Dimana nantinya pengguna akan terlebih dahulu memilih kriteria pelaku usaha yang ingin dicari. Kriteria tersebut berdasarkan jenis usaha, kecamatan, dan desa yang ada di Kabupaten Malang.

\subsection{SIG}

Istilah geografis merupakan bagian dari spasial atau keruangan. Kedua istilah ini sering digunakan secara bergantian atau tertukar hingga timbul istilah yang ketiga, geospasial. Ketiga istilah ini mengandung pengertian yang sama di dalam konteks SIG. Penggunaan kata geografis memiliki pengertian suatu persoalan mengenai permukaan bumi dua atau tiga dimensi.

Istilah informasi geografis mengandung pengertian informasi mengenai tempat-tempat yang terletak di permukaan bumi, pengetahuan mengenai posisi dimana suatu objek terletak di permukaan bumi, dan informasi mengenai keteranganketerangan atribut yang terdapat di permukaan bumi (Primadasa, 2015).

\subsection{UMKM}

UMKM di Kabupaten Malang mempunyai potensi sebagai penggerak perekonomian masyarakat. Potensi tersebut dapat dilihat dari jumlah pelaku usaha yang sangat besar dan selalu berkembang setiap tahun. Fungsi dan peran UMKM di Kabupaten Malang saat ini dirasakan amat penting. Selain sebagai sumber perekonomian banyak orang, tetapi juga sebagai penyedia lapangan kerja bagi sebagian besar masyarakat. Untuk itu, sangat dibutuhkan sebuah media untuk pelaku usaha mempromosikan usaha mereka dan mempermudah masyarakat luar maupun dalam Kabupaten Malang dalam mencari rute terdekat menuju pelaku usaha untuk mengefisiensi biaya dan waktu.

UUD yang mengatur adalah Undang-Undang No 20 Tahun 2008 bahwa pemerintah dan pemerintah daerah memfasilitasi pengembang usaha dengan cara memberikan intensif kepada usaha mikro, kecil, dan menengah mengembangkan teknologi dan kelestarian lingkungan hidup. Pada Undang- Undang nomor 20 tahun 2008 tentang UMKM, dijelaskan tentang kriteria UMKM tersebut. Dimana masing-masing kriteria UMKM memiliki tingkatan aset dan omset yang telah ditentukan oleh Undang-Undang tersebut (Suci, 2017).

\subsection{Android}

Android merupakan sistem operasi yang dikembangkan untuk perangkat mobile berbasis linux yang mencakup sistem operasi, middleware, dan aplikasi (Ir. Yuniar Supardi, 2014). Beberapa pengertian lain dari android yaitu:

1. Merupakan Open Source bagi para pengembang untuk membuat aplikasi.

2. Merupakan sistem operasi yang dibeli Google Inc. dari Android.Inc.

3. Bukan bahasa pemrograman, melainkan hanya menyediakan lingkungan yang disebut DVM (Dalvik Virual Machine) yang telah di optimasi untuk alat dengan sistem memori yang kecil

4. Untuk mengembangkan android, dibentuk OHA (Open Handset Aliance), konsorsium dari 34 perusahaan hardware, software, dan telekomunikasi, termasuk Google, HTC, Intel, Motorolam Qualcomm, dan Nvidia.

\subsection{Floyd Warshall}

Algoritma yang ditemukan oleh Warshall untuk mencari rute terpendek merupakan algoritma 
yang sederhana dan mudah implementasinya. Algoritma Floyd Warshall memiliki input graf berarah dan berbobot (V dan E) yang berupa daftar titik (node/titik V) dan daftar sisi (sisi E). Bobot garis e dapat diberi simbol w(e). Jumlah bobot sisi-sisi pada sebuah jalur adalah total bobot jalur tersebut. Sisi pada E diperbolehkan memiliki bobot negatif, akan tetapi tidak diperbolehkan bagi graf Wij untuk memiliki siklus dengan bobot negatif (Hasibuan, 2016). Algoritma ini menghitung bobot terkecil dari semua jalur yang menghubungkan sebuah pasangan titik, dan melakukannya sekaligus untuk semua pasangan titik demi titik hingga mencapai titik tujuan dengan jumlah bobot yang paling minimum (Siang, 2002). Algoritma Floyd Warshall untuk mencari lintasan terpendek adalah sebagai berikut:

1. $\mathrm{W}=\mathrm{W} 0$

2. Menentukan $\mathrm{k}=$ yang merupakan jumlah matriks perhitungan yang akan dibuat, dimulai dari 0 sampai nilai simpul pada graf berarah

3. Menentukan $\mathrm{i}$ dan $\mathrm{j}=$ nilai sesuai dengan simpul yang ada pada graf

4. Jika $\mathrm{W}[\mathrm{i}, \mathrm{j}]>\mathrm{W}[\mathrm{i}, \mathrm{k}]+\mathrm{W}[\mathrm{k}, \mathrm{j}]$ maka tukar $\mathrm{W}[\mathrm{i}, \mathrm{j}]$ dengan $W[i, k]+W[k, j]$

5. $\mathrm{W}^{*}=\mathrm{W}$

Keterangan:

- $\mathrm{W0}=$ matriks keterhubungan graf berarah berbobot awal

- $\mathrm{W}^{*}=$ matriks keterhubungan minimal

- $\mathrm{Wi}, \mathrm{j}=$ lintasan terpendek dari titik vi ke vj

\section{Metodologi}

Dalam membangun aplikasi pencarian rute terdekat ini, digunakan metode waterfall. Metode air terjun yang sering disebut metode waterfall, dimana metode ini menggambarkan pendekatan yang sistematis dan juga berurutan seperti analisis kebutuhan, desain sistem, penulisan kode program, dan pengujian program (Rachman \& Leidiyana, 2020). Tahapan metode waterfall dapat dilihat pada Gambar 1.

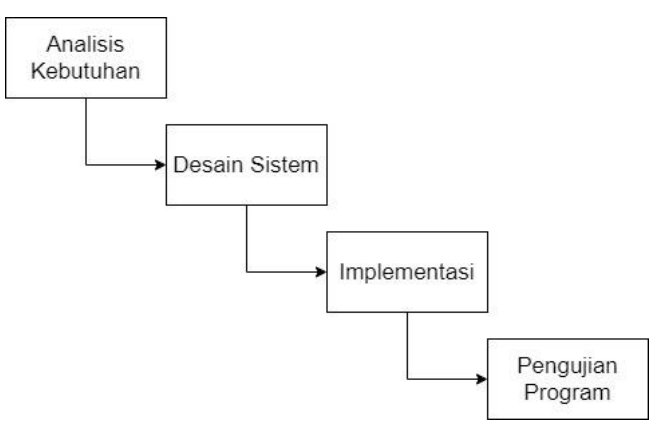

Gambar 1. Metode Waterfall

Tahapan dalam metode waterfall yang tersusun secara sistematis adalah sebagai berikut:
1. Analisis Kebutuhan

Data yang digunakan sebagai input adalah data UMKM, latitude, dan longitude yang nantinya terdapat pada basis data dari aplikasi berikut.Desain Sistem

2. Desain Sistem

Desain pembuatan program perangkat lunak digambarkan dengan Use Case, Activity Diagram, Flowchart, dan Entity Relationship Model (ERD).

3. Implementasi

Proses implementasi dilakukan dengan pemrograman berbasis android, pemrograman berbasis PHP, metode Floyd Warshall serta Android Studio dan Notepad ++ sebagai tools yang akan digunakan dalam pembuatan aplikasi.

4. Pengujian Program

Proses pengujian dilakukan dengan menggunakan metode Black Box Testing untuk mengetahui fungsionalitas sistem apakah sudah berjalan dengan baik.

\section{Perancangan}

\subsection{Gambaran umum Sistem}

Gambar 2 menjelaskan tentang alu dari aplikasi pencarian rute terdekat pelaku usaha UMKM. Data yang dimasukkan adalah data UMKM dari DISKOMINFO Kabupeten Malang. Selanjutnya data akan diolah sehingga menampilkan output berupa peta yang memberikan informasi berupa rute terdekat pelaku usaha mikro, kecil, dan menengah di Kabupaten Malang. Setiap pelaku usaha dibedakan berdasarkan kategori yang telah dibuat dalam database lalu dibedakan lagi berdasarkan kecamatan dan desa. Selain informasi rute terdekat, aplikasi ini juga menampilkan data dari pengusaha yang dicari oleh pengguna.

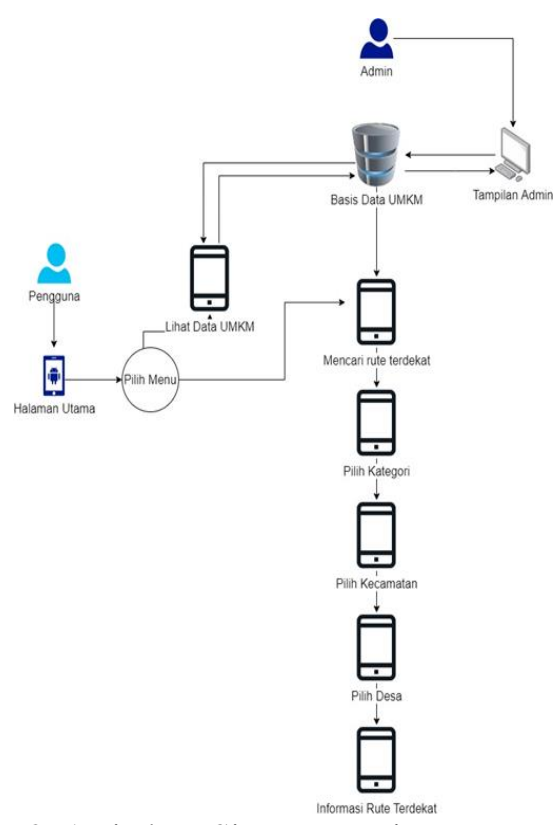

Gambar 2. Arsitektur Sistem Pecarian Rute Terdekat 


\subsection{Alur Perhitungan Floyd Warshall}

Algoritma Floyd Warshall merupakan salah satu algoritma pemrograman dinamis. Pada algoritma ini dilakukan pemecahan masalah dengan memandang solusi yang akan diperoleh sebagai suatu keputusan yang saling terkait. Artinya solusi tersebut dibentuk dari solusi yang berasal dari tahap sebelumnya dan ada kemungkinan lebih dari satu solusi (Darnita, Yulia dkk., 2017).

Gambar 3 menjelaskan tentang langkahlangkah yang dilakukan oleh algoritma Floyd Warshall dalam mencari rute terdekat. Pada bagian awal flowchart dilakukan perhitungan pada matriks iterasi K ke-n. Selanjutnya dilakukan proses perhitungan pada setiap bobot hingga iterasi ke-n. Perhitungan dilakukan dengan melakukan pengecekan. Bobot yang memiliki nilai terkecil akan dimasukan kedalam matriks perhitungan. Proses terus dilakukan hingga ditemukan matriks dengan bobot minimal. Langkah terakhir dari algoritma Floyd Warshall adalah menyimpan jarak yang terpilih.

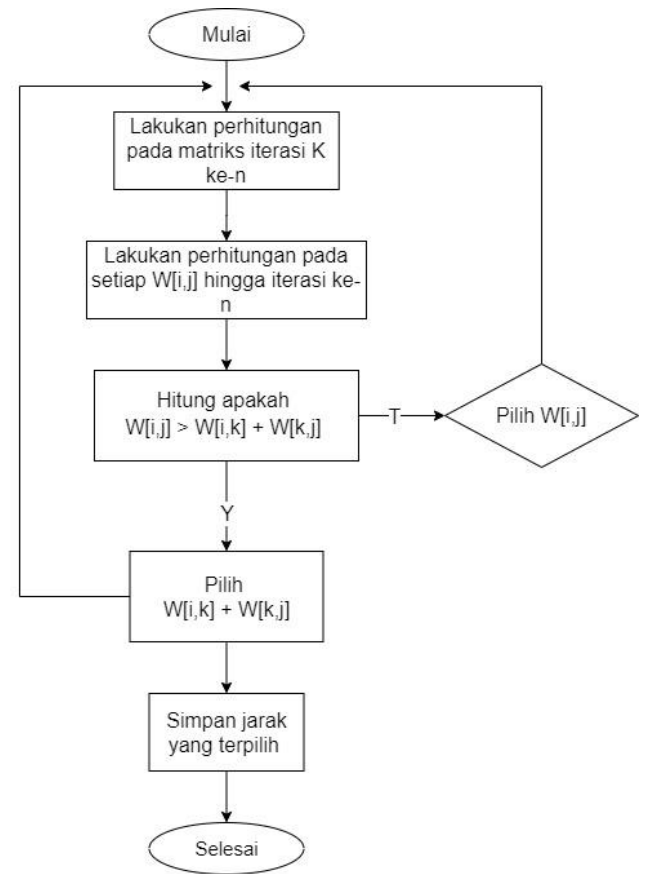

Gambar 3. Flowchart Algoritma Floyd Warshall

\subsection{Data}

Data yang digunakan pada penelitian adalah data UMKM yang berasal dari DISKOMINFO Kabupaten Malang. Data yang didapatkan diolah kembali sehingga data yang nantinya akan digunakan dalam penelitian ini berupa id daftar, nama usaha, alamat, rt, rw, nama pengusaha, desa, dan kecamatan. Pada data tersebut nantinya akan ditambahkan juga data latitude dan longitude yang didapatkan dari hasil observasi lokasi tiap pelaku usaha UMKM di Kabupaten Malang. Data UMKM yang digunakan dapat dilihat pada Tabel 1 dan Tabel 2.
Tabel 1. Datam UMKM 1

\begin{tabular}{|c|c|c|c|c|c|}
\hline $\begin{array}{l}\text { id_ } \\
\text { daft } \\
\text { ar }\end{array}$ & $\begin{array}{l}\text { nama_usah } \\
\text { a }\end{array}$ & alamat & $\begin{array}{l}\mathrm{r} \\
\mathrm{t}\end{array}$ & $\begin{array}{l}\mathrm{r} \\
\mathrm{w}\end{array}$ & desa \\
\hline 1 & $\begin{array}{l}\text { Warung } \\
\text { Kopi ST } \\
\text { dan Rokok } \\
\text { ST }\end{array}$ & $\begin{array}{l}\text { Ardirej } \\
\mathrm{O}\end{array}$ & 0 & 0 & Kepanejen \\
\hline 2 & $\begin{array}{l}\text { Mitra } \\
\text { Bukalapak } \\
\text { Jual Rokok }\end{array}$ & $\begin{array}{l}\text { JL. } \\
\text { Imam } \\
\text { Bonjol }\end{array}$ & 4 & 3 & Kepanejen \\
\hline 3 & $\begin{array}{l}\text { Toko } \\
\text { Sembako } \\
\text { Cak } \\
\text { Sugeng }\end{array}$ & $\begin{array}{l}\text { Pasar } \\
\text { Kepanj } \\
\text { en }\end{array}$ & 8 & 5 & Kepanejen \\
\hline 4 & Toko Ika & $\begin{array}{l}\text { JL. } \\
\text { Lawu }\end{array}$ & 0 & 0 & Kepanejen \\
\hline 5 & Toko Erni & $\begin{array}{l}\text { JL. } \\
\text { Ahmad } \\
\text { Yani }\end{array}$ & 0 & 0 & Kepanejen \\
\hline
\end{tabular}

Tabel 2. Data UMKM 2

\begin{tabular}{|l|l|l|l|l|}
\hline $\begin{array}{l}\text { nama_- } \\
\text { pengus } \\
\text { aha }\end{array}$ & kecamatan & $\begin{array}{l}\text { kategor } \\
\text { i }\end{array}$ & lat & lon \\
\hline $\begin{array}{l}\text { Tidak } \\
\text { Ada }\end{array}$ & Kepanjen & Rokok & $\begin{array}{l}- \\
8.131\end{array}$ & $\begin{array}{l}112.5 \\
82.83 \\
.590\end{array}$ \\
\hline Tidak & Kepanejen & Rokok & - & 112.5 \\
Ada & & & 8.111 & 67.99 \\
& & .193 & 0 \\
\hline Sugeng & Kepanejen & Semba & - & 112.5 \\
& & ko & 8.128 & 71.62 \\
& & .943 & 5 \\
\hline Ika & Kepanejen & Semba & - & 112.5 \\
& & ko & 8.131 & 62.50 \\
& & & .566 & 0 \\
\hline Erni & Kepanejen & Semba & - & 112.5 \\
& & ko & 8.120 & 74.08 \\
& & & .974 & 9 \\
\hline
\end{tabular}

\subsection{Usecase Diagram}

Use case diagram adalah diagram yang menyajikan interaksi antara use case dengan aktor. Dimana aktor dapat berupa orang, peralatan, atau sistem lain yang berinteraksi dengan sistem yang sedang dibangun. Use case menggambarkan fungsionaltias sistem atau persyaratan-persyaratan yang harus dipenuhi sistem dari sudut pandang pemakai. Use case dari aplikasi dapat dilihat pada Gambar 4. 


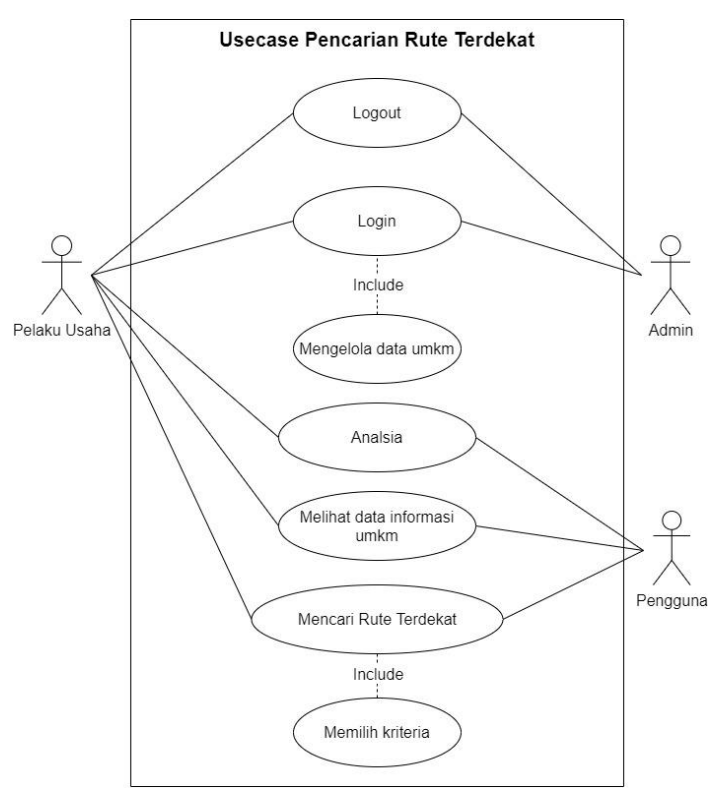

Gambar 4. Usecase Sistem Pencarian Rute Terdekat

\section{Implementasi}

\subsection{Implementasi Halaman Admin}

Halaman admin adalah web server dari aplikasi yang digunakan oleh pengguna. Halaman ini di akses melalui browser dan digunakan untuk mengelola data UMKM dan data jarak dari setiap pelaku usaha yang akan digunakan dalam menentukan rute terpendek pada aplikasi.

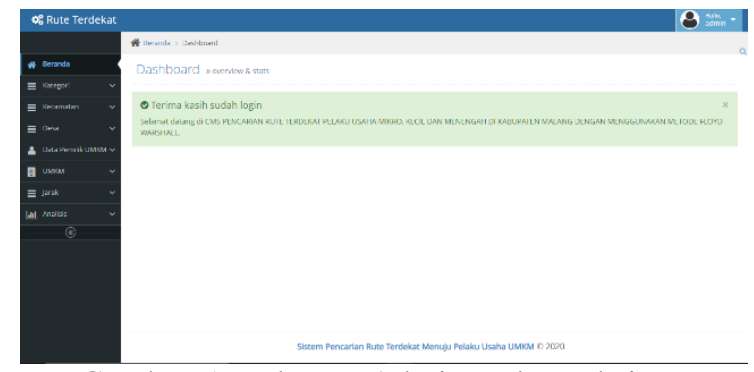

Gambar 5. Halaman Admin pada Website

\subsection{Implementasi Halaman Pelaku Usaha}

Halaman ini digunakan oleh pelaku usaha untuk mengelola data UMKM. Pelaku usaha dapat mengubah, menghapus, dan menambahkan data.

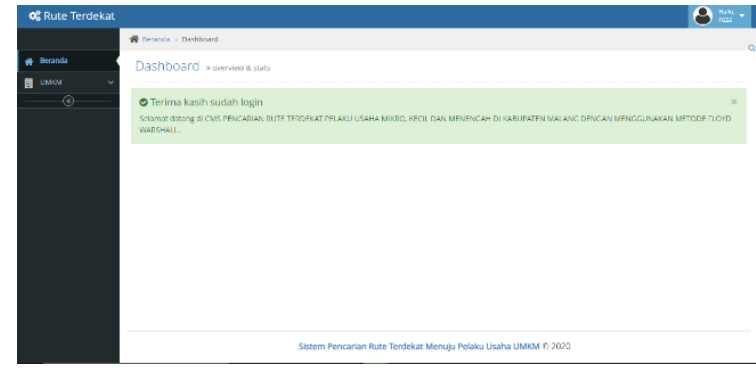

Gambar 6. Halaman Pelaku Usaha

\subsection{Implementasi Tampilan Pengguna}

Tampilan pengguna berada pada aplikasi yang dijalankan melalui smartphone android. Aplikasi ini digunakan oleh pengguna untuk melihat data informasi UMKM, melakukan pencarian rute terdekat, dan melakukan analisa jarak antar UMKM.

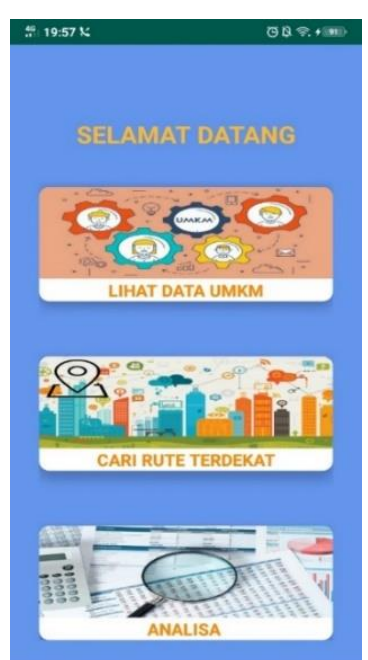

Gambar 7. Tampilan Pengguna pada Aplikasi

\section{Pengujian dan Hasil}

Pengujian algoritma Floyd Warshall untuk mengetahui apakah perhitungan pada algoritma sudah berjalan dengan baik dan memberikan hasil yang diinginkan. Pengujian dilakukan dengan melakukan pengecekan secara manual untuk menentukan apakah rute yang diambil sudah optimal atau tidak. Gambar 8 menunjukan tiga lokasi dengan kriteria yang sama lalu Gambar 9 adalah hasil dari perhitungan rute terdekat pada aplikasi. Dari Gambar 8 tersebut dilakukan perhitungan secara manual untuk melihat apakah hasilnya sama dengan yang ditunjukan oleh aplikasi.

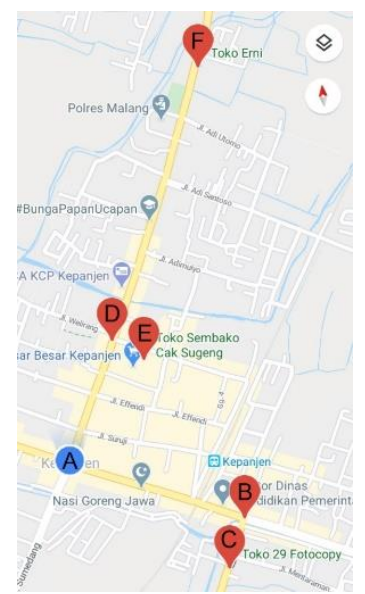

Gambar 8. Tiga Lokasi Dengan Kriteria Yang Sama 
Sebelum melakukan perhitungan perlu diketahui terlebih dahulu nilai $\mathrm{k}$, $\mathrm{i}$, dan $\mathrm{j}$. Nilai $\mathrm{k}$ adalah $(0,1,2,3,4,5,6)$ lalu nilai i dan $\mathrm{j}$ adalah $(\mathrm{A}, \mathrm{B}$, C, D, E, F). Langkah selanjutnya adalah melakukan perhitungan, berikut adalah hasil dari perhitungan algoritma Floyd Warshall dalam menentukan rute terdekat menuju pelaku usaha UMKM:

Tabel 3. Matriks x0

\begin{tabular}{|l|l|l|l|l|l|l|}
\hline & A & B & C & D & E & F \\
\hline A & 0 & $\begin{array}{l}0,564 \\
22\end{array}$ & $\infty$ & $\begin{array}{l}0,409 \\
60\end{array}$ & $\infty$ & $\infty$ \\
\hline B & $\begin{array}{l}0,564 \\
22\end{array}$ & 0 & $\begin{array}{l}0,171 \\
65\end{array}$ & $\infty$ & $\infty$ & $\infty$ \\
\hline C & $\infty$ & 0,171 & 0 & $\infty$ & $\infty$ & $\infty$ \\
\hline D & $\begin{array}{l}0,409 \\
60\end{array}$ & $\infty$ & $\infty$ & 0 & 0,123 & 0,901 \\
\hline E & $\infty$ & $\infty$ & $\infty$ & $\begin{array}{l}0,123 \\
81\end{array}$ & 0 & $\infty$ \\
\hline F & $\begin{array}{l}1,311 \\
51\end{array}$ & $\infty$ & $\infty$ & $\begin{array}{l}0,901 \\
90\end{array}$ & $\infty$ & 0 \\
\hline
\end{tabular}

Tabel 4. Matriks x1

\begin{tabular}{|l|l|l|l|l|l|l|}
\hline & A & B & C & D & E & F \\
\hline A & 0 & $\begin{array}{l}0,564 \\
22\end{array}$ & $\infty$ & $\begin{array}{l}0,409 \\
60\end{array}$ & $\infty$ & $\infty$ \\
\hline B & $\begin{array}{l}0,564 \\
22\end{array}$ & 0 & $\begin{array}{l}0,171 \\
65\end{array}$ & $\begin{array}{l}0,973 \\
82\end{array}$ & $\infty$ & $\infty$ \\
\hline C & $\infty$ & $\begin{array}{l}0,171 \\
65\end{array}$ & 0 & $\infty$ & $\infty$ & $\infty$ \\
\hline D & 0,409 & 0,973 & $\infty$ & 0 & 0,123 & 0,901 \\
& 60 & 82 & & 81 & 90 \\
\hline E & $\infty$ & $\infty$ & $\infty$ & 0,123 & 0 & $\infty$ \\
& & & 81 & & \\
\hline F & 1,311 & 1,875 & $\infty$ & 0,901 & $\infty$ & 0 \\
& 51 & 73 & & 90 & & \\
\hline
\end{tabular}

Tabel 5. Matriks x2

\begin{tabular}{|c|c|c|c|c|c|c|}
\hline & A & B & $\mathrm{C}$ & $\mathrm{D}$ & $E$ & $\mathrm{~F}$ \\
\hline A & 0 & $\begin{array}{l}0,564 \\
22\end{array}$ & $\begin{array}{l}0,735 \\
87\end{array}$ & $\begin{array}{l}0,409 \\
60\end{array}$ & $\infty$ & $\infty$ \\
\hline B & $\begin{array}{l}0,564 \\
22\end{array}$ & 0 & $\begin{array}{l}0,171 \\
65\end{array}$ & $\begin{array}{l}0,973 \\
82\end{array}$ & $\infty$ & $\infty$ \\
\hline C & $\begin{array}{l}0,735 \\
87\end{array}$ & $\begin{array}{l}0,171 \\
65\end{array}$ & 0 & $\begin{array}{l}1,145 \\
48\end{array}$ & $\infty$ & $\infty$ \\
\hline $\mathrm{D}$ & $\begin{array}{l}0,409 \\
60\end{array}$ & $\begin{array}{l}0,973 \\
82\end{array}$ & $\begin{array}{l}1,145 \\
48\end{array}$ & 0 & $\begin{array}{l}0,123 \\
81\end{array}$ & $\begin{array}{l}0,901 \\
90\end{array}$ \\
\hline $\bar{E}$ & $\infty$ & $\infty$ & $\infty$ & $\begin{array}{l}0,123 \\
81\end{array}$ & 0 & $\infty$ \\
\hline $\mathrm{F}$ & $\begin{array}{l}1,311 \\
51\end{array}$ & $\begin{array}{l}1,875 \\
73\end{array}$ & $\begin{array}{l}2,047 \\
39\end{array}$ & $\begin{array}{l}0,901 \\
90\end{array}$ & $\infty$ & 0 \\
\hline
\end{tabular}

Tabel 6. Matriks x3

\begin{tabular}{|l|l|l|l|l|l|l|}
\hline & A & B & C & D & E & F \\
\hline A & 0 & 0,564 & 0,735 & 0,409 & $\infty$ & $\infty$ \\
& & 22 & 87 & 60 & & \\
\hline B & 0,564 & 0 & 0,171 & 0,973 & $\infty$ & $\infty$ \\
& 22 & & 65 & 82 & & \\
\hline C & 0,735 & 0,171 & 0 & 1,145 & $\infty$ & $\infty$ \\
& 87 & 65 & & 48 & & \\
\hline D & 0,409 & 0,973 & 1,145 & 0 & 0,123 & 0,901 \\
& 60 & 82 & 48 & & 81 & 90 \\
\hline E & $\infty$ & $\infty$ & $\infty$ & 0,123 & 0 & $\infty$ \\
& & & & 81 & & \\
\hline F & 1,311 & 1,875 & 2,047 & 0,901 & $\infty$ & 0 \\
& 51 & 73 & 39 & 90 & & \\
\hline
\end{tabular}

Tabel 7. Matriks x4

\begin{tabular}{|l|l|l|l|l|l|l|}
\hline & A & B & C & D & E & F \\
\hline A & 0 & 0,564 & 0,735 & 0,409 & 0,533 & 1,311 \\
& & 22 & 87 & 60 & 42 & 51 \\
\hline B & 0,564 & 0 & 0,171 & 0,973 & 1,097 & 1,875 \\
& 22 & & 65 & 82 & 64 & 73 \\
\hline C & 0,735 & 0,171 & 0 & 1,145 & 1,269 & 2,047 \\
& 87 & 65 & & 48 & 30 & 39 \\
\hline D & 0,409 & 0,973 & 1,145 & 0 & 0,123 & 0,901 \\
& 60 & 82 & 48 & & 81 & 90 \\
\hline E & 0,533 & 1,097 & 1,269 & 0,123 & 0 & 1,025 \\
& 42 & 64 & 30 & 81 & & 72 \\
\hline F & 1,311 & 1,875 & 2,047 & 0,901 & 1,025 & 0 \\
& 51 & 73 & 39 & 90 & 72 & \\
\hline
\end{tabular}

Tabel 8. Matriks x5

\begin{tabular}{|l|l|l|l|l|l|l|}
\hline & A & B & C & D & E & F \\
\hline A & 0 & 0,564 & 0,735 & 0,409 & 0,533 & 1,311 \\
& & 22 & 87 & 60 & 42 & 51 \\
\hline B & 0,564 & 0 & 0,171 & 0,973 & 1,097 & 1,875 \\
& 22 & & 65 & 82 & 64 & 73 \\
\hline C & 0,735 & 0,171 & 0 & 1,145 & 1,269 & 2,047 \\
& 87 & 65 & & 48 & 30 & 39 \\
\hline D & 0,409 & 0,973 & 1,145 & 0 & 0,123 & 0,901 \\
& 60 & 82 & 48 & & 81 & 90 \\
\hline E & 0,533 & 1,097 & 1,269 & 0,123 & 0 & 1,025 \\
& 42 & 64 & 30 & 81 & & 72 \\
\hline F & 1,311 & 1,875 & 2,047 & 0,901 & 1,025 & 0 \\
& 51 & 73 & 39 & 90 & 72 & \\
\hline
\end{tabular}

Tabel 9. Matriks x6

\begin{tabular}{|l|l|l|l|l|l|l|}
\hline & A & B & C & D & E & F \\
\hline A & 0 & 0,564 & 0,735 & 0,409 & 0,533 & 1,311 \\
& & 22 & 87 & 60 & 42 & 51 \\
\hline B & 0,564 & 0 & 0,171 & 0,973 & 1,097 & 1,875 \\
& 22 & & 65 & 82 & 64 & 73 \\
\hline C & 0,735 & 0,171 & 0 & 1,145 & 1,269 & 2,047 \\
& 87 & 65 & & 48 & 30 & 39 \\
\hline D & 0,409 & 0,973 & 1,145 & 0 & 0,123 & 0,901 \\
& 60 & 82 & 48 & & 81 & 90 \\
\hline E & 0,533 & 1,097 & 1,269 & 0,123 & 0 & 1,025 \\
& 42 & 64 & 30 & 81 & & 72 \\
\hline F & 1,311 & 1,875 & 2,047 & 0,901 & 1,025 & 0 \\
& 51 & 73 & 39 & 90 & 72 & \\
\hline
\end{tabular}

Dari pengecekan secara manual tersebut dapat disimpulkan bahwa hasil dari perhitungan algoritma Floyd Warshall yang menunjukan rute terpendek dari pengguna adalah A-D-E dengan jarak 0,53342. Jika hasil pengecekan secara manual dibandingkan dengan hasil pencarian pada aplikasi, keduanya menampilkan hasil yang sama. Dari lokasi pengguna berada, terpilihlah rute terdekat menuju Toko Sembako Cak Sugeng. 


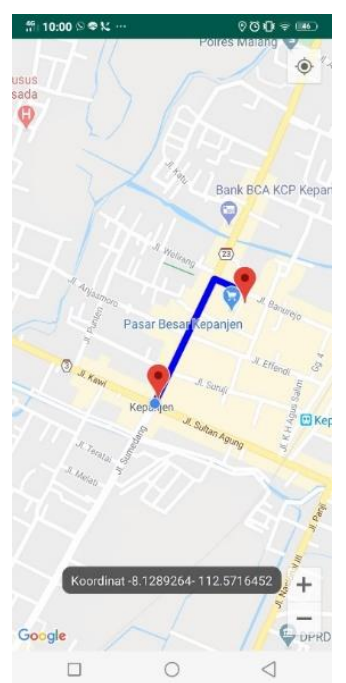

Gambar 9. Hasil Pencarian Pada Aplikasi

\section{Kesimpulan dan Saran}

\subsection{Kesimpulan}

Berdasarkan hasil dari perancangan aplikasi Pencarian Rute Terdekat Pelaku Usaha Mikro, Kecil, dan Menengah di Kabupaten Malang Pada Android, dapat di ambil beberapa kesimpulan, yaitu:

1. Halaman admin pada website ini dapat membantu Dinas Komunikasi Dan Informatika Kabupaten Malang dalam mengelola data UMKM dan menambahkan data lokasi dari setiap pelaku usaha. Pada proses perhitungan algoritma, admin diharuskan untuk menambahkan data jarak dari setiap pelaku usaha. Hal tersebut dibutuhkan untuk perhitungan algoritma yang digunakan. Aplikasi ini dapat membantu masyarakat yang berada di Kabupaten Malang dalam mengetahui informasi UMKM dan melakukan pencarian rute terdekat menuju pelaku usaha berdasarkan kriteria yang diinginkan.

2. Aplikasi ini dapat membantu masyarakat yang berada di Kabupaten Malang dalam mengetahui informasi UMKM dan melakukan pencarian rute terdekat menuju pelaku usaha berdasarkan kriteria yang diinginkan.

3. Dari hasil pengujian dan kuisioner yang diberikan kepada 5 responden dari pihak DISKOMINFO dan 20 responden yang merupakan masyarakat Kabupaten Malang, menunjukan bahwa aplikasi mampu berjalan dengan baik secara fungsional, mampu menampilkan data informasi dari pelaku usaha, dan memberikan hasil dari pencarian rute terdekat. Selain itu, halaman admin dapat memudahkan DISKOMINFO dalam mengelola data UMKM.

\subsection{Saran}

Saran penulisan terkait dengan perancangan aplikasi Pencarian Rute Terdekat Pelaku Usaha Mikro, Kecil dan Menengah di Kabupaten Malang Pada Android, untuk penelitian selanjutnya seperti berikut:

1. Untuk penelitian selanjutnya, sistem yang terdapat pada website dapat dibuat menjadi aplikasi android agar admin maupun pelaku usaha dapat mengakses dan mengelola data UMKM dimanapun.

2. Dalam menguji aplikasi, dapat digunakan metode lain seperti A-Star dan djikstra untuk dijadikan perbandingan tingkat keakurasian dalam penelitian lebih lanjut.

\section{Daftar Pustaka:}

Ariyanto, Y., Subhi, D. H., \& Wibowo, Y. T. (2019). PENDISTRIBUSIAN ELPIJI MENGGUNAKAN METODE FLOYD WARSHALL ( Studi Kasus : $P T$ Sulusindo Innovative ). Jurnal Informatika Polinema, 5, 214-215.

Awangga, R. M. (2019). Pengantar Sistem Informasi Geografis. Bandung: Kreatif Industri Nusantara. Kreatif Industri Nusantara.

Darnita, Yulia dkk. (2017). IMPLEMENTASI ALGORITMA FLOYD WARSHALL UNTUK MENENTUKAN LETAK DAN LOKASI PERUSAHAAN TRAVEL/RENTAL MOBIL DI KOTA BENGKULU. Jurnal Pseudocode, 4(2), 144-156.

Hasibuan, A. R. (2016). PENERAPAN ALGORITMA FLOYD WARSHALL UNTUK MENENTUKAN JALUR TERPENDEK DALAM PENGIRIMAN BARANG. Jurnal Riset Komputer, 3(6), 20-24.

Ir. Yuniar Supardi. (2014). Semua Bisa Menjadi Programmer Android Case study. Elex Media Komputindo.

Jubille Enterprise. (2016). Langkah Pertama Jadi Pengusaha UMKM. Jubilee Enterprise.

Kusmira, M., \& Taufiqurrochman. (2017). Pemanfaatan Aplikasi Graf Pada Pembuatan Jalur Angkot 05 Tasikmalaya.Seminar Nasional Sains Dan Teknilogi, 1-6.

Mukti, M. R., \& . Mulyono. (2018). Menentukan Rute Terpendek Dengan Menggunakan Algoritma Floyd-Warshall Dalam Pendistribusian Barang Pada Pt. Rapy Ray Putratama. KARISMATIKA: Kumpulan Artikel Ilmiah, Informatika, Statistik, Matematika Dan Aplikasi, 4(1).

Nawagusti, V. A. (2018a). Penentuan Rute Terpendek Pada Optimalisasi Jalur Pendistribusian Barang di PT. X dengan Menerapkan Algoritma Floyd-Warshall. Seminar Nasional Inovasi Dan Aplikasi Teknologi Di Industri, 57-64.

Nawagusti, V. A. (2018b). Penerapan Algoritma 
Floyd Warshall Dalam Aplikasi Penentuan Rute Terpendek Mencari Lokasi BTS (Base Tower Station) Pada PT.GCI Palembang. Jurnal Nasional Teknologi Dan Sistem Informasi, 4(2), 81-88.

Pangestuti, Edriana dkk. (2018). PETA POTENSI DALAM MENCIPTAKAN KEMANDIRIAN EKONOMI DESA (Studi pada Desa Tawang Argo, Kabupaten Malang). Journal of Applied Business Administration, 2(2), 258-266.

Primadasa, Y. (2015). Pencarian Rute Terpendek Menggunakan Algoritma Dijkstra Pada Sig Berbasis Web Untuk Distribusi Minuman. Jurnal KomTekInfo Ilmu Komputer, 2(2), 47-54.

Putra, A. H. (2016). Peran UMKM dalam Pembangunan dan Kesejahteraan Masyarakat Kabupaten Blora. Jurnal Analisa Sosiologi, 5(2), 40-52.

Rachman, A., \& Leidiyana, H. (2020). Sistem Informasi Fasilitas di DKI Jakarta Berbasis Android dengan Algoritma Floyd Warshall. Jurnal Komtika (Komputasi Dan Informatika), 4(1), 9-14.

Siang, J. J. (2002). Matematika Diskrit dan Aplikasinya pada Ilmu Komputer. ANDI.

Suci, Y. R. (2017). PERKEMBANGAN UMKM (USAHA MIKRO KECIL DAN MENENGAH) DI INDONESIA. Jurnal Ilmiah Cano Ekonomos, 6(1), 51-58.

Widya, F., \& Andrasto, T. (2016). Penerapan Algoritma Floyd-Warshall dalam Menentukan Rute Terpendek pada Pemodelan Jaringan Pariwisata di Kota Semarang. Jurnal Teknik Elektro, 8(1), 21-24. 